Vol. 2, No. 1, Desember 2021

\title{
PENYULUHAN JENIS-JENIS PEMBIAYAAN SYARIAH BAGI PEDAGANG KULINER DI DESA SENTELUK KECAMATAN BATULAYAR KABUPATEN LOMBOK BARAT
}

\author{
M. Irwan \\ Fakultas Ekonomi dan Bisnis Universitas Mataram \\ dae.wan65@yahoo.com \\ Muaidy Yasin \\ Fakultas Ekonomi dan Bisnis Universitas Mataram \\ fe.muaidy@gmail.com \\ Abdul Manan \\ Fakultas Ekonomi dan Bisnis Universitas Mataram \\ abdmananfeb@gmail.com \\ Siti Maryam \\ Fakultas Ekonomi dan Bisnis Universitas Mataram \\ maryamnanang@gmail.com
}

\begin{tabular}{|c|c|}
\hline Info Artikel & Abstrak \\
\hline $\begin{array}{l}\text { Diterima: } \\
\text { 30-11-2021 } \\
\text { Direvisi: } \\
\text { 24-12-2021 } \\
\text { Diterbitkan: } \\
\text { 24-12-2021 }\end{array}$ & $\begin{array}{l}\text { Terdesak oleh pemenuhan kebutuhan yang meningkat, } \\
\text { Tujuan dari kegiatan pengabdian kepada masyarakat ini } \\
\text { adalah memberikan pemahaman tentang (a) Arti, } \\
\text { kebijaksanaan pembiayaan syariah; (b) Jenis-jenis } \\
\text { pembiayaan syariah; (c), Manfaat pembiayaan syariah } \\
\text { dan (d) Perbedaan sistem pembiayaan syariahg dengan } \\
\text { suku bunga. } \\
\text { Kegiatan ini dapat dikatakan berjalan baik dan berhasil } \\
\text { dilihat dari beberapa indikator yaitu: (a) Peserta secara } \\
\text { saksama memperhatikan materi yang diberikan } \\
\text { meskipun disampaikan dengan metode ceramah yang } \\
\text { disertai dengan beberapa pertanyaan yang diajukan } \\
\text { berkenaan dengan kegiatan ini; (b) Peserta ingin } \\
\text { memulai usaha dengan berupaya menghimpun modal } \\
\text { sendiri maupun modal pinjaman secara bergulir. } \\
\text { Peserta membutuhkan modal usaha lain ketika usaha } \\
\text { yang dijalani sekarang mengalami penurunan jumlah } \\
\text { pembeli atau pelanggan; (c) Peserta penyuluhan telah } \\
\text { memiliki pengetahuan tambahan berkenaan dengan } \\
\text { pembiayaan syariah. Berdasarkan pengetahuan }\end{array}$ \\
\hline
\end{tabular}


tersebut dapat diterapkan pada usaha yang dijalani sekarang.

Saran yang berkenaan dengan kegiatan ini adalah Tim harus menindaklanjuti keinginan peserta untuk memberikan penyuluhan berkenaan dengan pemantapan pemahaman mengenai pembiayaan syariah yang disertai dengan conto-contoh aktual melaui kegiatan pendidikan atau pembinaan.dan Penyajian tim masih dalam bentuk ceramah, dikembangkan dalam bentuk pendidikan seperti mempraktekkan langkah-langkah memulai usaha dengan prinsip-prinsip Islami.

Kata Kunci: Pemuda, Pembiayaan, Pedagang Kuliner

DOI: 10.29303 /abdimassangkabira.v2i1.88

\section{PENDAHULUAN}

ANALISIS SITUASI

Manusia diperintahkan untuk melakukan bekerja dengan melakukan aktivitas yang sesuai dengan potensi dan kemampuan yang dimilikinya. Perintah bekerja ini dimaksudkan agar manusia dapat memenuhi berbagai kebutuhan hidupnya sehari-hari, baik untuk diri sendiri maupun keluarganya. Aktivitas usaha yang dapat dilakukan oleh manusia dapat dilakukan dengan kerja secara mandiri maupun bekerja pada orang lain dengan menerima upah atau imbalan atas tenaga dan waktu yang dicurahkan untuk melaksanakan pekerjaan tersebut. Dalam menjalankan aktivitas usahanya, manusia dihadapkan oleh berbagai kendala yang membutuhkan pengorbanan untuk dapat keluar dari kendala tersebut.

Salah satu jenis usaha yang dapat dilakukan oleh manusia pada umumnya adalah bekerja sebagai pedagang atau berbisnis dengan beragam jenis usaha yang dapat dilakukan. Usaha berdagang biasanya dilakukan secara bersama-sama atau berserikat dan lebih banyak dilakukan secara mandiri. Salah satu permasalahan yang dihadapi oleh pedagang dalam berusaha adalah permodalan. Sehingga dalam pelaksanaannya, banyak pengusaha yang memanfaatkan modal dengan melakukan pinjaman pada lembaga-lembaga keuangan baik perbankan maupun non bank konvensional maupun lembaga keuangan bank dan non bank syariah.

Usaha berdagang atau bisnis membutuhkan beberapa persyaratan di antaranya modal baik berupa modal tetap maupun modal lancar. Berkenaan dengan modal lancar, para pengusaha atau pebisnis memiliki keterbatasan dan jumlahnya relatif kecil, umumnyya menggunakan modal sendiri sehingga berdampak pada maju mundurnya usaha dan bisnis yang dilakukan. Oleh karenanya, banyak lembaga-lembaga keuangan konvensional dan syariah baik bank maupun non bank berupaya untuk 


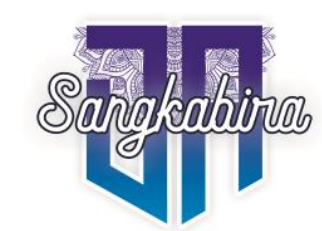

Vol. 2, No. 1, Desember 2021

membantu para pengusaha atau pebisnis dengan menawarakan berbagai produk-produk untuk memberikan pinjaman modal usaha kepada pengusaha.

Perbankan syariah yang tengah berkembang saat sekarang memiliki produk usaha berupa penghimpunan, pembiayaan dan jasa dengan skim yang berbeda-beda. Produk-produk tersebut masih banyak belum diketahui dan dipahami oleh masyarakat umum. Di antara berbagai skim yang ada adalah jenis-jenis pembiayaan syariah dengan berbagai sistem yang berada di dalamnya. Produk ini bagi kalangan tertentu sudah berhasabat dan telah melakukan transaksi dengan memanfaatkan skim ini. Namum masih banyak masyarakat yang belum memahami dan mengetahui prinsip kerjanya.

Pembiayaan syariah adalah proses penyaluran dana oleh lembaga keuangan syariah untuk diberikan kepada nasabah dengan prinsip-prinsip syariah. Pembiayaan tersebut terdiri dari berbagai jenis seperti jual beli, sewa menyewa, bagi hasil, pinjam meminjam (Mardani, 2015). Sistemsistem pembiaayaan ini dalam operasionalnya harus berdasarkan pada kaidah-kaidah fikih muamalah (Rozalinda, 2016). Sisi lain, para pengusaha yang melakukan usaha secara harus pula berdasarkan pada kaidah dan etika bisnis secara syariah sehingga mampu menggaapai kesuksesan dalam berusaha (Dawabah, 2005). Melakukan usaha diharapkan dapat melakukan usaha dengan melakukan wirausaha secara syariah, yaitu melakukan usaha dengan gagah berani, ulet, berani menanggung resiko yang tentunya berdasarkan pada prinsip-prinsip syariah (Farid, 2017).

Penduduk yang berada di desa Santeluk Kecamatan Batulayar Kabupaten Lombok Barat telah melakukan berbagai jenis usaha dagang salah satunya adalah berdagang kuliner. Mengingat kondisi alam desa Santeluk memiliki kawasan pantai yang panjang, sehingga masyarakat memanfaatkannya untuk melakukan usaha berdagang kuliner untuk dinikmati oleh masyarakat yang melakukan piknik di kawasan pantai tersebut. Dalam melakukan usahanya, para pedagang kuliner belum banyak memanfaatkan dana dari lembaga keuangan syariah sebagai modal usahanya. Mereka masih mengandalkan modal sendiri maupun melakukan pinjaman kepada lembaga-lembaga keuangan konvensional baik bank maupun non bank.

Kegiatan tim pengabdian berupaya untuk memberikan pengetahuan dan pemahaman kepada pengusaha pemula tentang jenis-jenis pembiayaan berbasis syariah dalam menjalani usahanya. Permasalahan yang dihadapi adalah masih relatif kurangnya pengetahuan dan pemahaman mereka tentang tatacara memperoleh pembiayaan usaha dari lembaga keuangan syariah dan syarat-syarat yang harus dipenuhi serta kewajiban-kewajiban lain yang berkenaan dengan kegiatan pembiayaaan. Sisi lain belum adanya lembaga keuangan mikro yang menyentuh langsung 
berkaitan denga modal usaha sehingga dalam mengembangkan usaha masih belum berjalan sesuai dengan yang diharapkan.

Berkenaan dengan permasalahan tersebut, maka pelaku aktivitas usaha sangat perlu untuk diberikan ilmu pengetahuan berkenaan dengan jenis-jenis pembiayaan syariah yang berada di lembaga keuangan syariah, Ilmu pengetahuan dapat diberikan melalui bentuk penyuluhan terutama sekali tertuju pada pedagang kuliner.. Hal ini dimaksudkan agar pelaku usaha pemula dapat mengetahui dari awal seluk beluk yang berkenaan dengan usaha termasuk cara memperoleh dan mengembalikan pembiayaan tersebut. Dengan adanya informasi ini akan membantu pedagang kuliner untuk dapat memperoleh modal usaha sekaligus mengembalikannya agar proses usaha baik lembaga pemberi pinjaman.

Permasalahan yang dihadapi oleh mitra sebagai berikut (1) Modal Usaha yang dimiliki oleh pedagang kuliner masih terbatas pada modal sendiri dan lembaga keuangan konvensional yang berdampak relatif lambannya perkembangan usaha(2) Keterbatasan informasi yang berkenaan dengan jenis-jenis pembiayaan yang berada pada lembaga keuangan syariah (3) Belum berfungsinya secara maksimal lembaga keuangan mikro khususnya berbasis syariah yang dapat menjembatani kebutuhan pedagang kuliner terhadap modal dalam jangka pendek.

\section{METODE PELAKSANAAN}

Permasalahan yang dihadapi oleh mitra dapat dipecahkan dengan melakukan kegiatan Pengabdian Kepada Masyarakat dalam bentuk kemitraan. Kegiatan yang dilakukan adalah memberikan penyuluhan dan pengetahuan tentang jenis-jenis pembiayaan syariah. Beberapa tahapan yang berkenaan dengan kegiatan ini adalah tahap persiapan, Pelaksaan, Pembinaan dan pendampingan hingga berjalannya lembaga keuangan non bank yang dibentuk.

\section{A. Tahap Persiapan}

Tahap persiapan meliputi kegiatan yang berkenaan dengan pelaksanaan yang akan dilakukan oleh tim pengabdian kepada masyarakat mulai dari perencanaan, penentuan waktu pelaksanaan, jumlah peserta hingga pelaksanaan penyuluhan. Langkah awal yang dilakukan adalah menghubungi kepala desa, koordinator pedagang kuliner, identifikasi peserta yang relevan dengan kegiatan ini.

B. Tahap Pelaksanaan

Tahap pelaksanaan merupakan waktu diadakannya kegiatan penyuluhan yang telah ditentukan didasarkan pada kesepakatan dengan kepala desa serta koordinator pedagang kuliner baik berkenaan dengan waktu maupun tempat pelaksanaan. Dalam tahap ini dilakukan tatap muka dengan peserta yang diawali dengan memberikan materimateri dengan metode ceramah yang berkaitan dengan jenis-jenis 
Vol. 2, No. 1, Desember 2021

pembiayaan syariah dan pemanfaatannya. Selanjutnya dilakukan diskusi berekenaan dengan materi maupun permasalahanpermasalahan yang dihadapi baik pada waktu awal maupun dalam menjalankan usaha.

Masyarakat yang dijadikan sasaran dari kegiatan penyuluhan ini adalah pedagang Kuliner khususnya yang berdagang di sekitar pantai Tanjung Bias, jumlah peserta yang diharapkan dan direncakanan akan mengikuti kegiatan penyuluhan ini maksimal sebanyak 25 orang dengan tidak membatasi jenis kelamin.

\section{METODE PELAKSANAAN}

Permasalahan yang dihadapi oleh mitra dapat dipecahkan dengan melakukan kegiatan Pengabdian Kepada Masyarakat dalam bentuk kemitraan. Kegiatan yang dilakukan adalah memberikan penyuluhan dan pengetahuan tentang konsep, karakteristik, prinsip-prinsi berwirusaha secara Islami. Pelaksanaan kegiatan dilakukan melalui beberapa tahap yaitu :

\section{Tahap Persiapan}

Tahap persiapan meliputi kegiatan yang berkenaan dengan pelaksanaan yang akan dilakukan oleh tim pengabdian kepada masyarakat mulai dari perencanaan, penentuan waktu pelaksanaan, jumlah peserta hingga pelaksanaan penyuluhan. Langkah awal yang dilakukan adalah menghubungi Lurah, kepala lingkungan dan tokoh pemuda, untuk melakukan identifikasi peserta yang relevan dengan kegiatan ini.

\section{Tahap Pelaksanaan}

Tahap pelaksanaan merupakan waktu diadakannya kegiatan penyuluhan yang telah ditentukan didasarkan pada kesepakatan dengan kepala lingkungan dan tokoh pemuda baik berkenaan dengan waktu maupun tempat pelaksanaan. Dalam tahap ini dilakukan tatap muka dengan peserta yang diawali dengan memberikan materi-materi dengan metode ceramah yang berkaitan dengan kewirausahaan islami.

\section{HASIL DAN PEMBAHASAN}

Pelaksanaan kegiatan penyuluhan dilaksanakan pada tanggal 31 Oktober 2021 yang dimulai jam 10.00 WITA hingga jam 12.30 WITA. Tempat melakukan kegiatan adalah tempat khusus tepatnya di usaha kuliner Pantai Tanjung Bias. Tempat pertemuan dilakukan pada sebuah balai pertemuan yang dikelola oleh Badan Usaha Milik Desa (BUMDES) desa Senteluk Kecamatan Batulayar Kabupaten Lombok Barat. Pemilihan waktu tersebut disesuaikan dengan waktu luang para peserta sebelum mereka melakukan aktivitas rutinnya sebagai pedagang kuliner. 
Kegiatan penyuluhan dihadiri oleh sekitar 20 orang peserta yang terdiri dari para pedagang kuliner yang berjenis kelamin laki-laki maupun perempuan dan tokoh masyarakat serta Pengengola Badan Usaha Milik Desa (BUMDES) setempat. Latar belakang peserta adalah pengusaha yang telah memiliki usahabaik usaha tetap maupun sementara waktu dan melakukan usahanya pada lapak-lapak yang telah disediakan dengan pemanfaataan secara kontrak (sewa).

Kegiatan penyuluhan dimulai dengan melakukan perkenalan antara tim pengabdian kepada masyarakat berkenaan dengan tujuan dan maksud diadakan kegiatan penyuluhan ini. Selanjutnya tim pengabdian menjelaskan dan menguraikan hal-hal yang berkenaan dengan pembiayaan baik yang dilakukan oleh lembaga keuangan konvensional maupun berdasarkan syariah Islam. Penyampain materi dilakukan secara umum dan disertai dengan contoh-contoh faktual tentang pelaksanaan pembiayaan yang berdasarkan prinsip kebersamaan dan sesuai dengan kaidah-kadiah syariah

Penyampaian materi penyuluhan adalah menguraikan berbagai dimensi atau unsur-unsur yang berkenaan dengan pembiayaan syariah atau secara islami bagi para pengusaha kuliner baik yang sudah memiliki usaha maupun yang belum memiliki usaha. Setelah tim menyampaikan materi kurang lebih 1 jam, kegiatan dilanjutkan dengan diskusi, dengan memberi kesempatan kepada peserta untuk bertanya dan menceritakan pengalaman tatkala sedang menjalani usaha serta langkah-langkah yang dilalukan ketika berhadapan dengan permasalahan permodalan. Beberapa pertanyaan yang diajukan oleh peserta berkenaan dengan permasalahan yang dihadapi adalah :

Salah satu peserta menanyakan tentang beberapa hal berkaitan dengan materi yang disampaikan yaitu :

1. Bagaimana cara berhubungan dengan lembaga keuangan tersebut mengingat terbatasnya kemampuan dan pemahamannya tentang perbankan syariah.

2. Apakah pembiayaan hanya ada di lembaga perbankan saja, atau ada yang lainnya. ?

Menjawab pertanyaan ini tim menyampaikan bahwa :

1. Lembaga keuangan syariah telah lama melaksanakan kegiatannya, dan memang masih membutuhkan kerja kerja dari pihak lembag keuangan syariah (bank dan non bank) untuk sering hadir ditengah-tengah masyarakat untuk melakukan sosialisasi baik berkenaan dengan eksistensinya maupun produk-produk yang diperhatikan.

Masyarakat umum dapat berhubungan dengan perbankan syariah dengan memanfaatkan berbagai produk dari lembaga keuangan syariah seperti menyimpan dana baik dalam bentuk tabungan maupun deposito. Juga dapat melakukan kegiatan pembiayaan dengan memenuhi berbagai 
syarat yang telah ditentukan bersama atau menggunakan jasa-jasa atau dalam bentuk sewa menyewa.

Masyarakat yang melalukan hubungan dengan bank dan menjadi nasabah baik dalam bentuk simpanan maupun pembiayaan, sistem yang dipergunakan adalah sistem bagi hasil bukan bunga seperti pada lembaga keuangan konvensional. Disinilah perbedaan prinsip antara lembaga keuangan syariah dan lembaga keuangan konvensional baik lembaga perbankan maupun lembaga keuangan non perbankan.

Dalam melakukan transaksi pembiayaan, pihak perbankan akan melakukan analisis pembiayaan yang dikenal dengan sebutan $5 \mathrm{C}$ yaitu (1) Character atau karakter, yaitu watak dari para calon nasabah; (2) Capacity (kapasitas/kemampuan) yaitu kemampuannya untuk melakukan usaha sekaligus kemampuan untuk menrgembalikan sejumlah pinjaman sesuai dengan akad; (3) Capital atau modal yaitu keyakinan nasabah dalam menjalankan usahanya; (4) Condition atau kondisi, yaitu keadaan nasabah yang berpengaruh secara langsung maupun tidak langsung terhadap perjalanan usaha nasabah; (5) Collateral (jaminan), yaitu jaminan yang dapat mendukung kegiatan usaha. Jika ke-5 hal ini telah dianggap cukup maka pihak lembaga keuangan syariah akan menyetujui prose transaksi dalam melalukan pembiayaan sesuai dengan yang diinginkan oleh para nasabah.

2. Menjawab pertanyaan ini tim mempertegas uraian sebelumnya bahwa lembaga keuangan syariah tidak hanya dalam bentuk perbankan namun ada yang berbentuk lembaga keuangan non bank seperti Asuransi Syariah, Pegadaian Syariah, Pasar Modal Syariah, Reksadana Syariah, Koperasi Syariah dan lainnya.

Dalam uraian ini, tim lebih menekankan pada koperasi syariah disesuaikan dengan bentuk usaha kuliner yang permodalan usahanya dapat diperoleh melalui koperasi syariah. Tim mendorong para pedagang kuliner dibawah koordinator Kepala Dusun sebagai penanggung jawab BUMDES membentuk koperasi syariah. Tim menceritakan pengalaman mengelola sebuah kegiatan yang menghimpun dana untuk digulirkan untuk kegiatan baik modal usaha maupun untuk kebutuhan lainnya. Lembaga ini diupayakan sebagai cikal bakal terbentuknya koperasi syariah.

Koperasi syariah merupakan salah satu lembaga keuangan non bank seabagai wadah bagi pedagang kuliner dapat memenuhi berbagai kebutuhan hidup salah satunya adalah modal usaha. Dengan terbentuknya koperasi, permasalahan modal dapat diatasi karena tidak menanggung beban bunga serta hasil keuntungannya dapat dinikmati bersama. Terutama di masa pandemi Covid-19 ini, dimana segala aktivitas mengalami kelesuan bahkan tidak sedikit yang menutup 
usahanya karena berkurangnya pembeli dan modal habis untuk memenuhi kebutuhan hidup.

Menanggapi apa yang disampaikan oleh tim, kepala Dusun menjelaskan bahwa segala bentuk peminjaman uang yang menerapkan sistem bunga dengan berbagai istilah yang diberikan masyarakat seperti bank subuh, bank rontok dan lainnya tidak diperkenankan beroperasi di sektiar kawasan Tanjung Bias ini. Hal ini dilakukan karena banyak sekali kerugian yang dialami oleh pedagang terutama berkenaan dengan besarnya modal dan sistem pengembalian yang memberatkan mereka dengan penerapan tingkat bunga. Masyarakat tidak bisa bergerak karena pada waktu-waktu tertentu sudah datang menagih meski pedangan mengalami kerugian.

Peserta yang lain juga yang merupakan suami dari pengelola BUMDES merasa tertarik materi dan contoh yang disampaikan oleh tim. Bahkan dia meminta tim ini memjadi pembina dan memberikan praktik secara langsung mengenai sistem pembiayaan yang tidak berbasis bunga sehingga masyarakat tidak lagi menjalani usaha yang bertentangan dengan ajaran agama.

Menanggapi hal ini, tim telah memberikan kesanggupannya baik dilakukan pada kegiatan yang sama dalam bentuk pembinaan atau pendidikan pada masa-masa mendatang. Tim memberikan contoh tentang praktek yang telah dijalankan oleh tim berkenaan dengan kegiatan peminjaman tanpa bunga. Tim menyatakan ada beberapa orang yang memiliki kelebihan pendapatan berkumpul mengumpulkan uang dalam bentuk zakat, infaq, sedekah maupun bentuk lainnya dengan besaran tertentu setiap bulannya. Dana itu dipergunakan dengan tujuan tujuan untuk memberikan bantuan kepada orang yang membutuhkan untuk keperluan modal atau kebutuhan yang lainnya.

Misalnya terkumpul uang sebesar Rp 5.000.000,-. Dari 10 orang dermawan.

1. Ada seseorang yang sangat membutuhkan uang untuk modal usaha dan diberikan pinjaman sebesar Rp 1.000.000,- . Akad yang terjadi antara kedua belak pihak adalah bahwa dalam kegiatan ini tidak diadakan tambahan dari besarnya modal (bunga). Namun peminjam harus menyatakan bahwa ia harus bersikap jujur dan bertanggung jawab. Dari besarnya modal tersebut diberikan informasi bahwa kegiatan ini adalah bersifat sosial dan tolong menolong dalam kebaikan, sehingga diminta keikhlasannya untuk memberikan sedekah atau infaq secara sukarela untuk menambah modal.

2. Sistem pengembalian pinjaman dilakukan secara angsuran sesuai dengan kesepakatan misalnya selama 10 kali. Jika dapa perjalanannya ada bulan yang tidak diangsur pembayarannya, tidak dikenanakan denda dan diberi kelonggaran untuk membayar pada bulan-bulan berikutnya. 


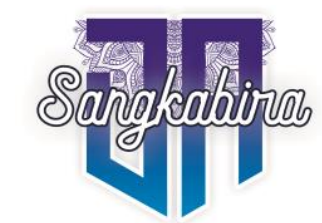

Vol. 2, No. 1, Desember 2021

3. Pada saat pelunasan peminjaman, peminjam memberian infaq atau sedekah secara sukarela sebesar Rp 50.000,- untuk menambah modal. Besaran ini tidak diberikan penekanan khusus, dan jikapun tidak ada tidak apa-apa yang penting prinsip yang dipegang adalah jujur dan tanggung jawab.

4. Berdasarkan informasi yang diberikan oleh peminjam pertama pada orang lain maka peminjam semakin bertambah dari waktu ke waktu dengan besaran yang bervariatif dan jangka waktu yang berbedabeda pula.

5. Untuk tahap awal kegiatan ini, tim telah memberikan suntikan dana awal kepada kepala Dusun untuk digulirkan kepada pedagang kuliner yang sangat membutuhkan pada saat ini.
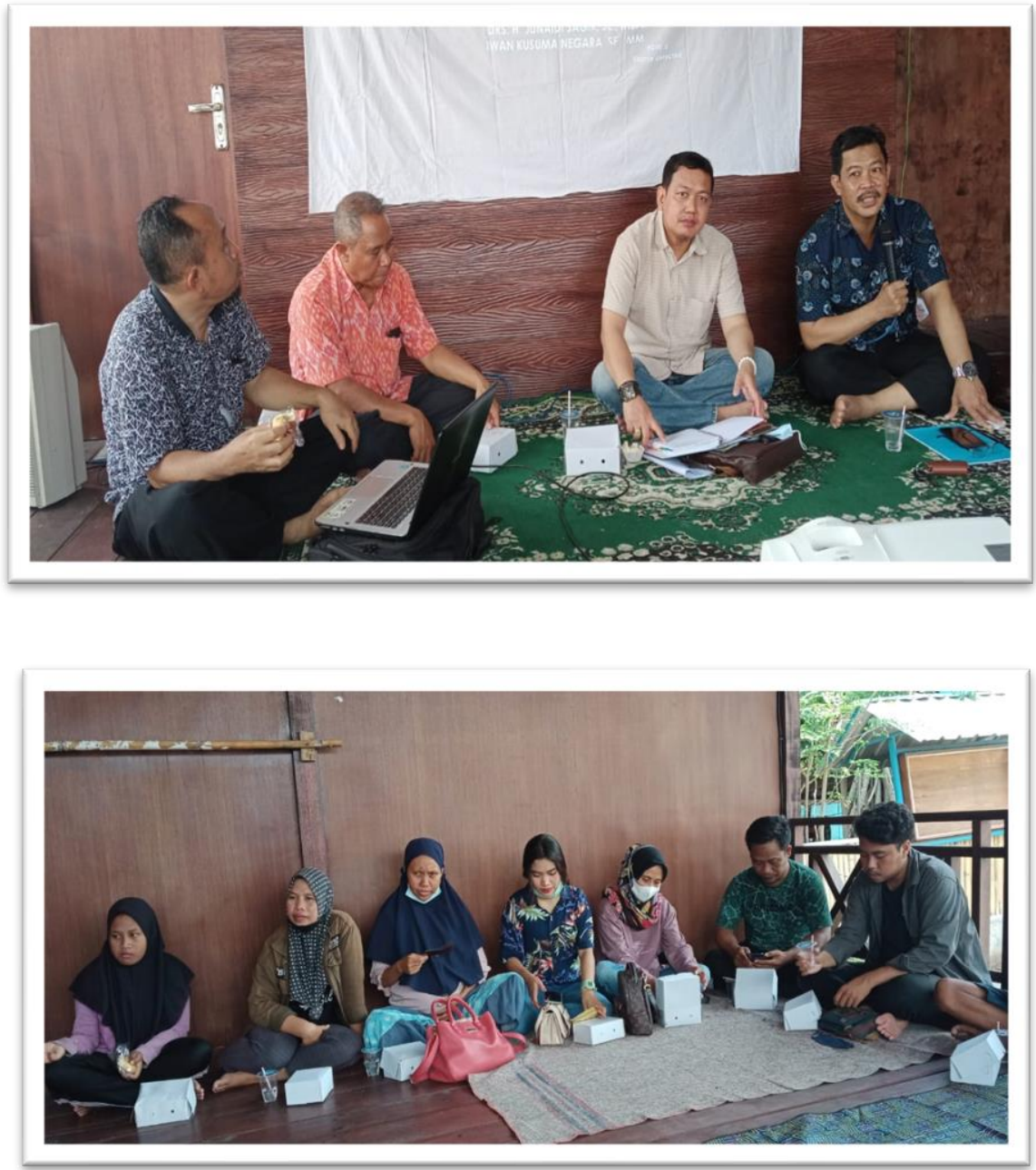

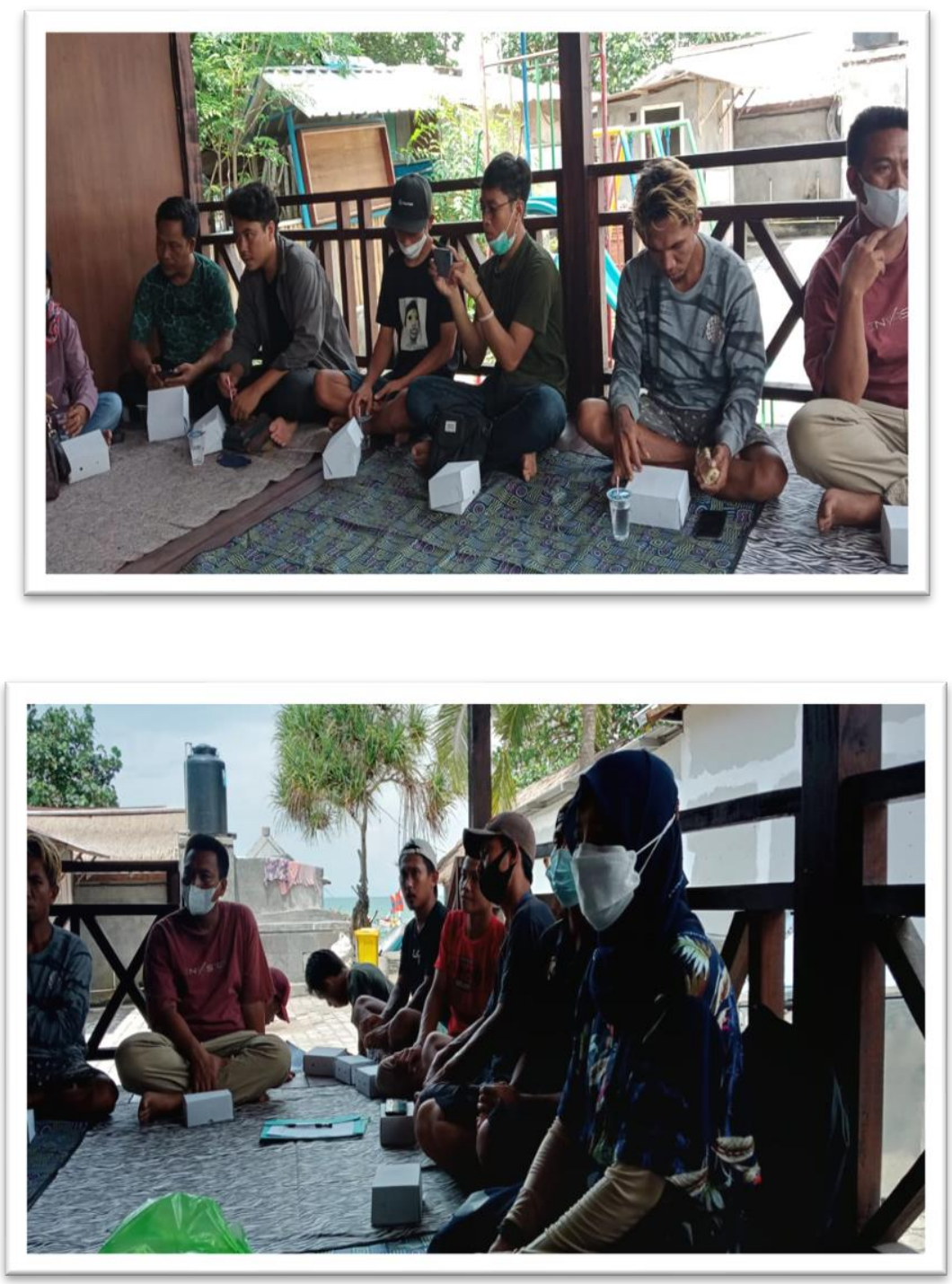

Materi yang disampaikan oleh tim pengabdian telah mampu memberikan tambahan pengetahuan kepada peserta sehingga dapat dijadikan informasi yang dapat dipergunakan jika akan memulai dan melanjutkan usaha. Berdasarkan hasil diskusi dan tanya jawab yang telah dilakukan, dapat diketahui permasalahan yang dihadapi oleh peserta. Beberapa pertanyaan dari peserta dan merupakan permasalahan yang dihadapi peserta dapat dihimpun sebagai berikut :

1. Peserta memiliki pengetahuan yang terbatas berkenaan dengan arti makna, kebijaksanaan, jenis-jenii, manfaat pembiayaan dan perbedaan antara prinsip bagi hasil pada lembaga keuangan syariah dengan prinsip bunga pada perbankan konvensional.

2. Usaha yang dijalani oleh pedagang kuliner di pantai Tanjung Bias mengalami penurunan selama covid-19 bahkan ada di antaranya yang mengalihkan usahanya kepada orang lain. 


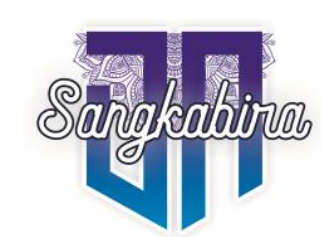

Vol. 2, No. 1, Desember 2021

3. Para pedagang kuliner menghadapi permasalahan kekurangan atau tidak lagi memiliki modal usaha sejak terjadinya pandemi covid-19 dan tidak ada tempat untuk memperoleh modal dengan pinjaman lunak

4. Belum dipahaminya secara utuh tentang keberadaan perbankan syariah berkaitan dengan produk-produk yang dihasilkan terutama pada aspek pembiayaan dengean berbagai jenis dan manfaat yang dapat diperoleh bila memanfaatkan pembiayaan tersebut.

Berdasarkan pertanyaan dan identifikasi permasalahan tersebut, tim pengabdian telah memberikan penjelasan dan uraian secara umum berkenaan dengan permasalahan yang tengah dihadapi. Tim juga memberikan pandangan tentang prinsip meraih keungan maksimal secara islami yang diperbolehkan sepanjang tidak mendholimi pihak (konsumen) yang membutuhkan barang tersebut. Tim juga memberikan pengetahuan tentang hal-hal yang harus diperhatikan dalam berusaha seperti jujur, tidak berbohong, tidak melakukan kecurangan serta harus dapat dipercaya dan mampu melaksanakan amanah yang diberikan pihak lain kepada dirinya.

\section{KESIMPULAN DAN SARAN \\ Simpulan}

Berdasarkan hasil pelaksanaan pengabdian pada masyarakat dan pembahasan di atas dapat ditarik beberapa simpulan sebagai berikut :

1. Kegiatan penyuluhan telah berjalan dengan baik, peserta yang hadir sesuai dengan jumlah yang ditargetkan. Pelaksanaan kegiatan tidak sepenuhnya mengikuti protokol kesehatan seperti menjaga jarak karena tempat kegiatan yang relatif terbatas.

2. Peserta secara saksama memperhatikan materi yang diberikan meskipun disampaikan dengan metode ceramah yang disertai dengan beberapa pertanyaan yang diajukan berkenaan dengan kegiatan ini.

3. Peserta ingin memulai usaha dengan berupaya menghimpun modal sendiri maupun modal pinjaman secara bergulir. Peserta membutuhkan modal usaha lain ketika usaha yang dijalani sekarang mengalami penurunan jumlah pembeli atau pelanggan.

4. Peserta penyuluhan telah memiliki pengetahuan tambahan berkenaan dengan pembiayaan syariah. Berdasarkan pengetahuan tersebut dapat diterapkan pada usaha yang dijalani sekarang.

\section{Saran -saran}

Berdasarkan hasik kegiatan ini dapat diberikan saran - saran konstruktif sebagai berikut :

1. Tim harus menindaklanjuti keinginan peserta untuk memberikan penyuluhan berkenaan dengan pemantapan pemahaman mengenai pembiayaan syariah yang disertai dengan conto-contoh aktual melaui kegiatan pendidikan atau pembinaan. 
2. Penyajian tim masih dalam bentuk ceramah, dikembangkan dalam bentuk pendidikan seperti mempraktekkan langkah-langkah memulai usaha dengan prinsip-prinsip Islami.

\section{DAFTAR PUSTAKA}

Asyraf Muhammad Dawabah, 2005, The Moslem Entepreneur, Kiat Sukses Pengusaha Muslim, Zikurl Hakim, Jakarta.

Farid, 2017, Kewirausahaan Syariah, Kencana, Jakarta

Karim, Adiwarman A. 2006. Bank Islam Analisis Fiqih dan Keuangan. PT. RadjaGrafindo Persada. Jakarta.

Mardani. 2012. Fiqh Ekonomi Syariah; Fiqh Muamalah. Kencana Prenada Media Group; Jakarta.

2015. Aspek Hukum Lembaga Keuangan Syariah Di Indonesia. Kencana Prenada Media Group; Jakarta.

Nikensari, Sri Indah. 2012. Perbankan Syariah Prinsip, Sejaran dan Aplikasinya. PT. Pustaka Rizki Putra, Semarang.

Nurhasanah, Neneng. 2015. Mudharabah Dalam Teori dan Praktek. PT. Refika Aditama, Bandung.

Rozalinda, 2016. Fikih Ekonomi Syariah Prinsip dan Implementasinya Pada Sektor Keuangan Islam. P. RadjaGrafindo Persada, Jakarta.

Sjahdaeni, Sutan Remy. 2014. Perbankan Syariah; Produk-Produk dan Aspek-Aspek Hukumnya. Kencana PrenadaMedia Group. Jakarta.

Umam, Khaerul, 2013.Manajemen Perbankan Syariah. CV. Pustaka Setia,Bandung.

Zulkifli, Sunarto. 2007. Panduan Praktis Transaksi Perbankan Syariah, Edisi Revisi. Zikrul Hakim, Jakarta. 